\title{
The Impact of Internet Financial Reporting Practices on the Company's Market Value: A Study of Listed Manufacturing Companies in Indonesia
}

\author{
Adityawarman $^{1}$, Yusuf Khudri T.B.M. ${ }^{1 *}$ \\ ${ }^{1}$ Faculty of Economics and Business, Universitas Indonesia, Depok 16424, Indonesia \\ *yusufkh@ui.ac.id
}

\begin{abstract}
This research aims to examine the impact of Internet Financial Reporting (IFR) practices on the market value of Indonesian manufacturing companies' listed on the Indonesia Stock Exchange between 2015 and 2016. This research examines how information available on company websites affects a firm's market value based on efficient market hypotheses, agency theory, and signaling theory. Using 79 firms as the research sample, this research finds empirical evidence that IFR practices have a strong positive relationship to market values over the research period. Overall, the results indicate that investors value IFR information as a source for making equity pricing decisions. The results have implications for both national regulators and entities regarding the importance of information openness.
\end{abstract}

Keywords: Internet Financial Reporting, Market Value.

\section{INTRODUCTION}

With the rapid development of technology in recent years, the use of the internet in Indonesia has increased significantly $^{1,2}$. The number has always increased annually from 2005 to 2014 , from 7.8 percent to 34.9 percent $^{3}$. Increased internet usage occurs because the internet has the benefit of conveniently providing and obtaining information at any time and place ${ }^{1}$.

With the increasing use of the internet, many companies have used their official website to disclose financial and nonfinancial information ${ }^{1,2,4-6}$, so that the use of the internet has changed the presentation of traditional corporate information. The practice of disclosing financial and nonfinancial information through internet media is called Internet Financial Reporting (IFR) ${ }^{1}$. This research aims to examine the impact of IFR practice on the market value of Indonesian manufacturing companies listed on the Indonesia Stock Exchange between 2015 and 2016. This research contributes to knowledge by examining how IFR affects manufacturing companies in Indonesia's market value.

\section{LITERATURE REVIEW AND HYPOTHESIS DEVELOPMENT}

Companies in emerging markets, including Indonesia, have been investing in internet technology since the 1990s, meaning that IFR practices in Indonesia have experienced a lengthy process to date ${ }^{7}$. The age of the company listing affects the IFR practices of the company ${ }^{8}$. IFR practice aims to provide a medium of communication to investors who require information as a consideration of investment, meaning that the availability of information on a company's website provides convenience in assessing its performance ${ }^{9}$. In the presence of IFR practices, accounting information becomes more accessible to users of financial statements ${ }^{10}$. Currently, IFR is becoming important due to the geographic spread of investors residing in a country and interstate regions, and traditional hardcopy disclosure methods have serious and less timely limitations ${ }^{11}$. In the current era of globalization, investors and potential investors can be in different geographic areas, thus IFR is a useful method to accelerate the delivery of information to be used as part of the decision-making process because the information is available through company sites that can be accessed at any time and place ${ }^{12}$. IFR also enables the company to be more transparent, with information provided to users of financial statements so that information asymmetry between management and investors is reduced ${ }^{5}$. In addition, disclosure via the internet can reduce the cost of corporate information disclosure, as companies do not have to provide hardcopy reporting as before the existence of IFR practices ${ }^{4,8}$.

The practice of IFR is related to agency theory and signaling theory, whereby both theories have a relationship with the investor ${ }^{8}$. Given this relationship, company management will tend to disclose information in order to maximize its relationship with investors, and IFR practices are one of the channels for providing information as 
required by agency contracts ${ }^{2}$. In addition, the company can give a signal to investors about the advantages of what is owned by the company compared to other companies ${ }^{13}$, so that IFR becomes a channel through which to express positive signals to the public, especially investors ${ }^{2}$.

There are two researches that have been carried out to determine the role of the internet in spreading the company's information from the standpoint of users of the company's financial statements. In 2012, a study found that investors and global analysts prefer the source of information through digital devices rather than hardcopy ${ }^{14}$. According to a study of users' perceptions of financial statements in Indonesia, most users of financial statements often use the internet as a medium to seek financial information, mainly through the company's official website, and all users of the sample financial statements agree that IFR makes it easier for them to obtain company information ${ }^{15}$. This indicates that users of current financial statements have been using the internet as a medium to find information on corporate financial statements.

To improve the quality of corporate information disclosure, in 2012, the capital market regulator BAPEPAMLK issued Decree No. 431/BL/2012, with Article 3 requiring companies to publish an annual report on their official website. Regulations on the obligation of information disclosure through a company's website were re-established in 2015 when the Financial Services Authority (OJK) issued regulation number 8/ POJK.04, which governs the provisions of the issuer's or public company's website. Unlike the previous BAPEPAM-LK regulation that only requires the disclosure of annual reports, this regulation provides further information on what should be posted on a company's website. With the enactment of this rule, investors have an alternative to obtaining information as a hardcopy report form, with information now delivered more quickly to the users of the report.

A firm's market value is calculated using the stock price on the capital market multiplied by the number of shares outstanding ${ }^{16}$. Maximizing a company's market value through its stock price in order to increase investor wealth is the goal of the company's financial management, as, investors invest to obtain a return from the company. In order for this to occur, the company must have good performance in managing the profit and risk of the company so that the company's value and the investor's wealth will increase ${ }^{17}$. Shareholder wealth will increase due to the distribution of dividends or capital gains derived from the increase in stock prices ${ }^{18}$. Financial and nonfinancial information is required to know how the company performs in each period; therefore, financial and nonfinancial information must be published so that investors can always assess the company's market value through stock prices. In order to understand the relationship between IFR practices and a firm's market value, market value is calculated based on the share price at the time of publication of annual financial statements multiplied by the number of shares outstanding ${ }^{11}$. The company's market value is influenced by factors such as firm size, leverage, liquidity, and profitability ${ }^{19-22}$.

With IFR practices conducted through a company's website ${ }^{1,2,4-6}$, investors now have official access to company sites that disclose information and news that the company has released. The existence of IFR practices makes relevant financial and nonfinancial information available that can contribute to the decision-making process ${ }^{9}$. This research aimed to find out whether the existence of information disclosure through IFR practices reflects on stock prices according to the efficient market hypothesis ${ }^{23}$, whereby IFR practices have an influence on the market value of a company at the time of the financial report's publication. Market value is an important indicator because investors can obtain capital gain by increasing the company's market value through the stock price ${ }^{18}$; therefore, investors certainly hope that the company invested in has high corporate value. Thus, we hypothesize:

\section{Hypothesis1: Internet Financial Reporting will have a positive impact on market value of a firm.}

\section{RESEARCH METHOD}

This research uses a quantitative approach by conducting a hypothesis test to explain the correlation between, and significance of, the IFR practice of a company and its market value, to determine whether or not IFR practice has an influence on the market value of a company. This study uses the research time range between 2015 and 2016 at manufacturing companies listed on the Indonesia Stock Exchange. The type of data used in this study is secondary data, where the data obtained does not come directly from the source but is taken from other sources ${ }^{24}$. The source of this research data is obtained through the Indonesia Stock Exchange website, the Yahoo Finance site, and the official sites of the sample companies.

This study uses nonprobability sampling whereby the selected sample is not based on random probability. The method used is purposive sampling, where the sample selection is based on predetermined criteria. This research makes the manufacturing company as research sample. The sampling technique can be seen in table 1, below. 
Table.1. Sample Selection Criteria

\begin{tabular}{lc}
\hline \multicolumn{1}{c}{ Sample Selection Criteria } & Qty \\
\hline $\begin{array}{l}\text { Companies listed in the manufacturing sector } \\
\text { on IDX for the year 2015-2016 }\end{array}$ & 143 \\
Companies' IPO in 2015 or change sectors & $(5)$ \\
Companies that meet the time criteria & 138 \\
$\begin{array}{l}\text { Companies that do not have a website or do } \\
\text { not practice IFR }\end{array}$ & $(41)$ \\
Companies that practice IFR & 97 \\
$\begin{array}{l}\text { Companies that undertake reporting with } \\
\text { foreign currency }\end{array}$ & $(14)$ \\
Companies with negative equity value & $(4)$ \\
Companies used as samples & 79 \\
\hline
\end{tabular}

To find the relevance of the value of corporate reporting through the internet, this study uses the Ohlson ${ }^{25}$ model that many researchers use to find the relevance of the value of the IFR level ${ }^{11}$. This study uses several control variables to take into account the influence of firm characteristics into the analysis results. The control variables that will be used are company size, profitability, liquidity, and leverage level, where the four variables affect the company's market value ${ }^{19-22}$. By considering the control variable, the regression model is determined as follows:

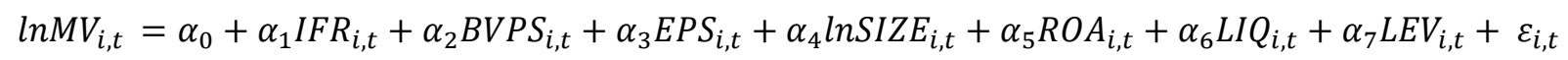

LNMV : The natural logarithm value of the company's market value at the end of the fourth month of the fiscal year, at the time of publication of the annual report

IFR : The number of disclosures based on The Internet Disclosure index ${ }^{26}$

BVPS : The book value of shareholders' equity at the end of the financial year

EPS : The value of the company's earnings per share at the end of the financial year as calculated based on the value of profit after tax is divided by the number of shares outstanding

LNSIZE : The firm size measured by the natural logarithm of the value of assets owned by the company at the end of the financial year

ROA : The corporate profitability as measured by the return on asset

LIQ : The corporate liquidity as measured by the current ratio

LEV : The firm's leverage rate is measured by the debt to equity ratio

\section{RESULT AND DISCUSSIONS}

Based on the observation results and the index component assessment of companies' websites, a variation of scores was found between companies with regards to IFR practices. With the variation of scores, grouping IFR score of companies to seven intervals. The extent of corporate IFR disclosure can be seen in Figure 1, which shows the IFR score level of the firm. The 10 to 19 percent interval is the interval with the lowest number of firms. Companies at this interval only upload the financial statements of the current year on the company website. The company does not upload annual reports or interim financial reports on the company's website, nor any other index component. This indicates that the company still has many shortcomings in terms of corporate information disclosure, reporting format, and user support on the company website. The information content is limited to the year-end financial statements.

There are nine companies at the highest interval, 70 to 79 percent. These companies already have a good implementation of IFR practices because the content of disclosed information, reporting formats, and user support meet the index criteria well. The disclosed content includes financial information, corporate governance information, and CSR information already reported almost complete. The company websites also have adequate user support through providing a site map, search engine, and one-click function to obtain investor information. 


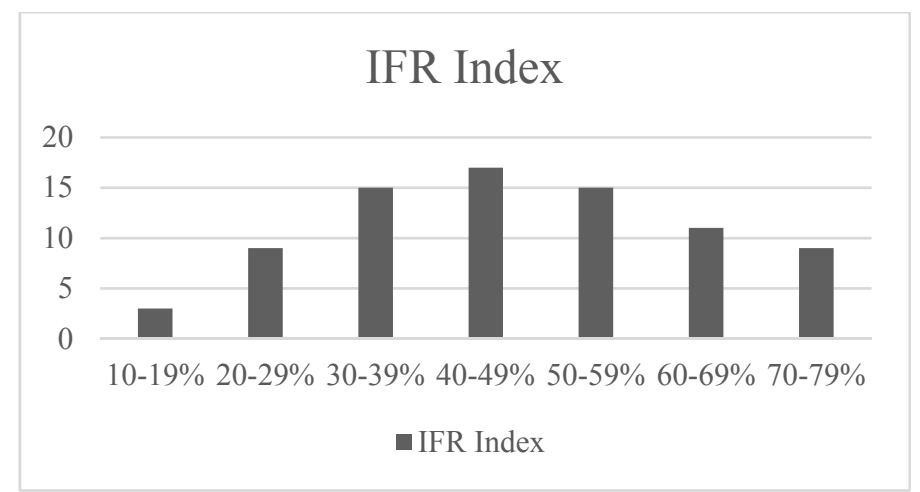

Fig.1. Company's IFR Index Distribution Chart

From observations and ratings on the company websites, no company reports financial information in a processable format such as XBRL or a spreadsheet. Almost all companies produce financial reports in PDF format, with some in HTML format. This is consistent with previous research in 2012 which found that none of the companies in the study used a financial analysis tool on the website ${ }^{12}$. One of the things that can explain this finding is that there is no specific regulation that requires companies to use the XBRL format. A 2014 study that examined users' perceptions of financial statements in Indonesia against IFR practices, found that 96 percent of the respondents did not like the XBRL format ${ }^{15}$, which could be one of the reasons why companies do not use it.

Companies' websites in general already provide user convenience in the form of a single click that takes them to the investor relations page and news or press releases, from the main page. With a single click from the main page, visitors can immediately see the investor relations page and corporate news. Other important components are the site map and search engine, technology that half of the companies are already using. Sitemaps can provide a broad overview of the pages displayed on the company website and visitors can go directly to the page they want. The search engine is a useful feature for finding specific information on a company's website. The following is the result of descriptive statistics derived from research observation:

Table.2. Descriptive Statistics

\begin{tabular}{cccccc}
\hline Variable & $\begin{array}{c}\text { Observat } \\
\text { ion }\end{array}$ & Mean & $\begin{array}{c}\text { Std. } \\
\text { Dev }\end{array}$ & Min & Max \\
\hline mv & 158 & $\begin{array}{c}21.939 \\
\text { billion }\end{array}$ & $\begin{array}{c}67.152 \\
\text { billion }\end{array}$ & $\begin{array}{c}34 \\
\text { billion }\end{array}$ & $\begin{array}{c}457.827 \\
\text { billion }\end{array}$ \\
ifr & 158 & 0,47 & 0,16 & 0,12 & 0,78 \\
bvps & 158 & 1.676 & 3.074 & 54 & 16.652 \\
eps & 158 & 281 & 841 & $-124,7$ & 8.132 \\
size & 158 & 9.826 & 29.639 & 100 & 245.435 \\
roa & 158 & 0,066 & 0,090 & $-0,184$ & 0,44 \\
liq & 158 & 5,545 & 36,870 & 0,51 & 464,98 \\
lev & 158 & 1,236 & 1,409 & 0,0004 & 8,7 \\
\hline
\end{tabular}

To find the correlation between independent and dependent variables and its significance, and to determine whether the hypothesis is accepted or rejected, linear regression analysis was undertaken. Table 3 shows the results of multiple linear regression with random effect.

The probability value $\mathrm{F}$ of 0.0000 in table 3 shows that the independent variables and control variables simultaneously have a significant influence on the dependent variable, i.e. the market value of the firm. It can be concluded that the model of this study can simultaneously explain the relationship between independent variables and control variables on the market value of the company. The R-squared value of 0.7230 indicates that the seven independent variables in this research model have the ability to explain the dependent variable of 72.30 percent. The remaining 27.7 percent is explained by other variables not included in this research model. It can be concluded that the independent variable in this research model has been good in explaining what factors affect companies' market value.

Based on table 3, the IFR variable has a significance value of 0.000 , whereby IFR is something that positively affects the market value of a company. This conclusion simultaneously accepts the hypothesis in this study that IFR practice has a positive influence on companies' market value. The results of this study are consistent with a previous study which concludes that IFR practices have value relevance to a firm's market value ${ }^{11}$. These results 
conclude that investors use the information disclosed through a company's website to assess the said company, owing to the ease of accessing relevant information both quickly and inexpensively. The information disclosed is a signal for investors to assess the company. The disclosed information reduces the information asymmetry between the management of a firm and its investors, meaning that a company's IFR practices can always be monitored by investors.

\begin{tabular}{|c|c|c|c|c|c|c|}
\hline \multirow[t]{10}{*}{$\begin{array}{l}\text { F-Statistics: } \\
\text { R-squared: }\end{array}$} & $\begin{array}{r}59,56 \\
0,7354\end{array}$ & $\begin{array}{l}\text { Prob F: } \\
\text { Adj R-Squ }\end{array}$ & $\begin{array}{r}\text { Table. } 3 \\
\\
\text { ared: } \quad 0\end{array}$ & $\begin{array}{l}\text { Regression } \\
00 \\
30\end{array}$ & Results & \\
\hline & & Var. & Coef. & $\begin{array}{c}\text { Std. } \\
\text { Error }\end{array}$ & t-Stat & Prob. \\
\hline & & IFR & 1,722928 & 0,710861 & 2,423719 & 0,0000 \\
\hline & & BVPS & $-1,17 \mathrm{E}-05$ & $1,88 \mathrm{E}-05$ & $-0,620821$ & 0,2678 \\
\hline & & EPS & $-3,04 \mathrm{E}-05$ & 0,000143 & $-0,212056$ & 0,4162 \\
\hline & & LNSIZE & 1,020535 & 0,067868 & 15,03703 & 0,0000 \\
\hline & & ROA & 0,042982 & 0,007834 & 5,486765 & 0,0000 \\
\hline & & LIQ & 0,003344 & 0,003428 & 0,975432 & 0,1654 \\
\hline & & LEV & $-0,167397$ & 0,049071 & $-3,411348$ & 0,0004 \\
\hline & & $\mathrm{C}$ & $-1,746649$ & 1,740667 & $-1,003437$ & 0,1586 \\
\hline
\end{tabular}

The results of this research are consistent with the results of previous research that has examined the perceptions of users of financial statements in Indonesia against IFR practices ${ }^{15}$. The study concludes that users of financial statements in Indonesia perceive that the information disclosed by a company through its website is accurate, relevant, and easy to obtain. Given these advantages, users of financial statements, especially investors, will use the information displayed on a company website to make decisions.

\section{CONCLUSION}

This study aimed to test whether the IFR practices undertaken by manufacturing companies in Indonesia have a positive influence on their market value. The results of this study indicate that IFR practices have a significant positive effect on firms' market value in addition to other dominant factors, namely, firm size, profitability, and levels of corporate leverage. These results are in accordance with previous research which states that IFR practices have value relevance to firms' market value because investors use the information disclosed on a company's website to assess the company. The results of this study's observations found that there is variation in the level of disclosure amongst the companies sampled. Some companies only reveal little information on their site, while other companies reveal sufficient information. It can be concluded that there are still many companies that have not utilized internet technology to provide relevant information for investors through their websites, and that there are also many companies that do not update on the site. The results of this study found that investors perceive the practice of IFR as something that is important; therefore, it has a positive influence on a company's market value, which could arise from the ease with which users of financial statements are able to obtain company information through official company sites. The regulator needs to support and enforce the rules that have been made in relation to the disclosure of information through a company website. OJK Regulation No. 8, from 2015, has stated the information that needs to be disclosed on a company's website to improve information disclosure to the public. In fact, there are still many companies that have not fully complied with the regulation, which needs to be enforced by OJK. Management needs to make sure that the disclosure of information through company websites is carried out effectively in order to reduce information asymmetry between management and investors. There are still many companies that have not optimized the internet to disclose company information. The disclosure of relevant information is beneficial to companies, as investors can provide an assessment of the company based on available information. This study has several limitations, i.e. the sample used in this study is relatively small amount so that less can be generalized to the population. The value of the disclosure rate is assumed to be the same every year due to the limitations on knowledge of any content changes to company websites from previous years. The recommendation for further research is to use companies from various sectors in the research sample, in order to understand the impact of IFR practices in general for all company sectors while also increasing the number of samples.

\section{REFERENCES}

[1] E. R. Maryati. The effect of Internet Financial Reporting (IFR) on firm value, stock price, and stock return in the manufacturing companies listed in Indonesia Stock Exchange, The Indonesian Accounting Review, (2014).

[2] N. M. Chandra. Analisis pengaruh Internet Financial Reporting (IFR) dan tingkat pengungkapan informasi melalui website terhadap frekuensi perdagangan saham (studi kasus pada perusahaan yang terdaftar dalam Indeks Kompas-100 tahun 2010), (2011).

[3] Profil Pengguna Internet Indonesia 2014. Downloaded on 22 October https://apjii.or.id/downfile/file/PROFILPENGGUNAINTERNETINDONESIA2014.pdf (2015).

[4] H. Ashbaugh, K. M. Johnstone, T. D. Warfield. Corporate reporting on the internet, Accounting Horizons, (1999). 
[5] Z. D. Rahman. The impact of Internet Financial Reporting on stock prices moderated by corporate governance: evidence from Indonesia Capital Market, Social Science Research Network, Rochester, New York (2010).

[6] R. Debreceny, G. L. Gray, A. Rahman. The determinants of Internet Financial Reporting, Journal of Accounting and Public Policy, (2002).

[7] S. A. Hunter and L. M. Smith. Impact of Internet Financial Reporting on emerging markets, Journal of International Business Research, (2009).

[8] H. S. Lestari and A. Chariri. Analisis faktor-faktor yang mempengaruhi pelaporan keuangan melalui internet (Internet Financial Reporting) dalam website perusahaan, Undergraduate Thesis, UNDIP (2007).

[9] D. A. Akbar and D. Daljono. Analisis faktor yang mempengaruhi pengungkapan laporan perusahaan berbasis website, Diponegoro Journal of Accounting, (2014).

[10] M. Ettredge, V. J. Richardson, and S. Scholz. The presentation of financial information at corporate web sites, International Journal of Accounting Information Systems, (2001).

[11] A. H. Ahmed, Y. A. Tahat, B. M. Burton, and T. M. Dunne. The value relevance of corporate internet reporting: the case of Egypt, Advances in Accounting, (2015).

[12] A. Kristian. Analisis pengaruh reputasi auditor, umur perusahaan, struktur kepemilikan, dan jenis industri terhadap pengungkapan informasi keuangan melalui website perusahaan, (2012).

[13] E. Sukanto. Pengaruh Internet Financial Reporting dan tingkat pengungkapan informasi website terhadap frekuensi perdagangan saham perusahaan di bursa, Fokus Ekonomi, (2011).

[14] Global Reporting Initiatives. The value of extra-financial disclosure what investors and analysts said, (2012).

[15] I. A. Yurano. Persepsi pengguna laporan keuangan di Indonesia terhadap Internet Financial Reporting, Undergraduate Thesis, Universitas Indonesia, (2014).

[16] J. Livnat and D. Segal. The calculation of earnings per share and market value of equity: should common stock equivalents be included?, (2000).

[17] S. A. Ross, R. W. Westerfield, and J. Jaffe. Corporate finance, 9th edition, McGraw-Hill/Irwin, New York (2009).

[18] C. P. Jones, S. Utama, B. Frensidy, I. A. Ekaputra, and R. U. Budiman. Investments analysis and management 10th edition an Indonesian adaptation, John Wiley \& Sons, (2008).

[19] P. Gunarso. Laba akuntansi, leverage, dan ukuran perusahaan terhadap harga saham di BEI, Jurnal Keuangan dan Perbankan, (2014).

[20] S. Hermuningsih. Profitability, growth opportunity, capital structure and the firm value, Bulletin of Monetary, Economics and Banking, (2013).

[21] R. Amanah, D. Atmanto, and D. F. Azizah. Pengaruh rasio likuiditas dan rasio profitabilitas terhadap harga saham (studi pada perusahaan Indeks LQ45 periode 2008-2012), Jurnal Administrasi Bisnis, (2014).

[22] O. A. G. Hassan, P. Romilly, G. Giorgioni, and D. Power. The value relevance of disclosure: evidence from the emerging capital market of Egypt, The International Journal of Accounting, (2009).

[23] E. F. Fama. Efficient capital markets: a review of theory and empirical work, The Journal of Finance, (1970).

[20] U. Sekaran and R. Bougie. Research methods for business : a skill building approach, Wiley, (2011).

[21] K. Ota. A test of the Ohlson (1995) model: empirical evidence from Japan, The International Journal of Accounting, (2002).

[26] L. Spanos and J. Mylonakis. Internet corporate reporting in Greece, European Journal of Economics, Finance and Administrative Sciences, (2006) 